\title{
Systematic Evaluation and Meta-Analysis of the Efficacy and Safety of Shenfu Injection in the Treatment of Septic Cardiomyopathy
}

\author{
Rui Wu' ${ }^{1}$, Meng Li ${ }^{1,2^{*}}$ \\ ${ }^{1}$ Shaanxi University of Chinese Medicine, Xianyang 712046, Shaanxi Province, China \\ 2Department of Lung Diseases, Shaanxi Provincial Hospital of Chinese Medicine, Xi'an 710004, Shaanxi Province, China \\ *Corresponding author: Meng Li, zmwq7812@sina.com \\ Copyright: () 2022 Author(s). This is an open-access article distributed under the terms of the Creative Commons Attribution License (CC \\ BY 4.0), permitting distribution and reproduction in any medium, provided the original work is cited.
}

\begin{abstract}
Objective: To evaluate the efficacy and safety of Shenfu injection in the treatment of septic cardiomyopathy. Methods: Literatures on Shenfu injection for the treatment of sepsis published from the establishment of each database to December 31, 2020, were searched by computer; Cochrane risk-of-bias tool was used for evaluating the quality of literatures, and Review Manager 5.4 software was used for meta-analysis. Results: Twenty random controlled trials (RCTs) were included, with a total of 1,179 patients; the meta-analysis showed that the routine treatment of Western medicine combined with Shenfu injection can reduce the 28-day mortality, the length of hospital stay, cardiac troponin I (cTnI), and N-terminal pro-brain natriuretic peptide (NT-proBNP) as well as improve the left ventricular ejection fraction (LVEF) with low incidence of adverse reactions. Conclusion: Western medicine combined with Shenfu injection can further reduce myocardial injury in patients with sepsis and improve cardiac function as well as the prognosis of patients with septic cardiomyopathy.
\end{abstract}

Keywords: Shenfu injection; Septic cardiomyopathy; Effectiveness; Safety; Meta-analysis

Online publication: January 19, 2022

\section{Introduction}

Septic cardiomyopathy is one of the important reasons for the rapid progress and deterioration of patients with sepsis ${ }^{[1]}$. Nearly half of the patients with sepsis have cardiomyopathy, and its mortality is as high as $70 \%{ }^{[2]}$. Septic cardiomyopathy is a short-term reversible cardiac dysfunction ${ }^{[3]}$. Therefore, it is extremely important to take effective measures to reverse the myocardial injury and restore the cardiac function in time in septic patients.

Septic cardiomyopathy is a common complication in the mid and late stages of sepsis. Its main pathogenesis is the deficiency and decline of Yang Qi, and its main treatment includes strengthening and supplementing Qi as well as warming Yang. Shenfu injection can protect the myocardium, improve myocardial contractility, and regulate peripheral circulation. At present, it is mainly used in the treatment of various heart diseases, such as shock and heart failure ${ }^{[4]}$. Although studies have shown that Shenfu injection combined with conventional western medicine can reduce myocardial injury and improve cardiac function, prognosis, as well as the curative effect ${ }^{[5,6]}$, there is a lack of large sample evidence support. Therefore, a meta-analysis on the efficacy and safety of Western medicine combined with Shenfu injection in the treatment of septic cardiomyopathy is carried out, so as to provide evidence-based basis for clinical treatment. 


\section{Materials and methods}

\subsection{Inclusion and exclusion criteria}

\subsubsection{Inclusion criteria}

(1) Research type: RCTs published at home and abroad as of December 31, 2020.

(2) Subjects: Patients with sepsis, regardless of gender, aged $\geq 18$ years, without any significant difference in baseline data before treatment.

(3) Interventions: The experimental group received the conventional treatment of Western medicine combined with Shenfu injection, while the control group only received the conventional treatment of Western medicine, without restrictions in the usage, dosage, and treatment time.

(4) Outcome indicators: At least one of the following - 28-day mortality rate, length of stay in ICU, cTnI, NT-ProBNP, and LVEF.

\subsubsection{Exclusion criteria}

Literatures of the same group of patients; unclear treatment time; inconsistent outcome indicators; animal experiments; cases, reviews, and literatures in which the full text cannot be obtained.

\subsection{Literature retrieval strategy}

PubMed, Embase, CNKI, Wanfang, and other databases were searched by computer from the establishment date of each database to December 31, 2020, without language restriction. The English keywords used to search were "ShenFu injection," "sepsis," "septic shock," and "RCT." The Chinese keywords used were “参附注射液,”“脓毒症,”“脓毒性休克,” and “感染性休克.” Each keyword was searched by collocation.

\subsection{Data extraction}

The articles were imported into Endnote; they were duplicated and deleted according to the inclusion and exclusion criteria. Upon reading the title, literatures such as reviews, animal experiments, and those with drug nonconformity were excluded. The researchers browsed the full text carefully and eliminated some literatures, such as those with non-randomized controlled trials and outcome index nonconformity. Two researchers screened the literatures independently and checked each other. When there were differences, the third researcher ruled. Data including basic information, sample size, intervention methods, treatment time, outcome indicators, etc. were extracted.

\subsection{Quality evaluation}

Cochrane risk-of-bias tool was used to evaluate the quality of the studies one by one ${ }^{[7]}$, and whether the outcome indicators were affected was the only criterion. The results of the assessment were represented by Cochrane risk-of-bias bar chart with red, yellow, and green dots.

\subsection{Statistical analysis}

RevMan 5.4, which is a statistical analysis software, was used, and the results were represented by forest plots. In this study, the continuous variables were analyzed by mean difference (MD) and the binary variables by relative risk (RR). The confidence interval (CI) was 95\%. Chi-square test was used to evaluate the heterogeneity between studies; when $\mathrm{P}>0.1, \mathrm{I}^{2}<50 \%$, and there is no heterogeneity, the fixed effect model is selected for meta-analysis; when $\mathrm{P}<0.1, \mathrm{I}^{2} \geq 50 \%$, and there is heterogeneity, the random effect 
model is used for meta-analysis. When the heterogeneity is too large, only descriptive analysis is carried out. The stability of the results was evaluated by eliminating the literatures one by one for sensitivity analysis. Funnel plot was used to evaluate the publication bias of the literatures with outcome index $\geq 10$.

\section{Results}

\subsection{Literature search results and basic characteristics}

A total of 984 literatures were retrieved. Taking into consideration of the exclusion criteria, 20 literatures were included in the statistical analysis ${ }^{[5,6,8-25]}$, all of which were Chinese literatures. The retrieval process is shown in Figure 1. In total, 1,179 patients were included. There were 13 literatures with the outcome of 28-day mortality rate ${ }^{[5,8-13,17,19-21,24,25]}$, and 8 literatures with the outcome of ICU stay ${ }^{[5,10,12,17,19,21-22,24]}$; there were 5 literatures with cTnI outcome index ${ }^{[5,6,14,16,23]}, 6$ literatures with NT-ProBNP outcome index [5,11, 14-15, 18,23], and 4 literatures with LVEF outcome index ${ }^{[6,15-16,18]}$. The basic characteristics of the included literatures are listed in Table 1.

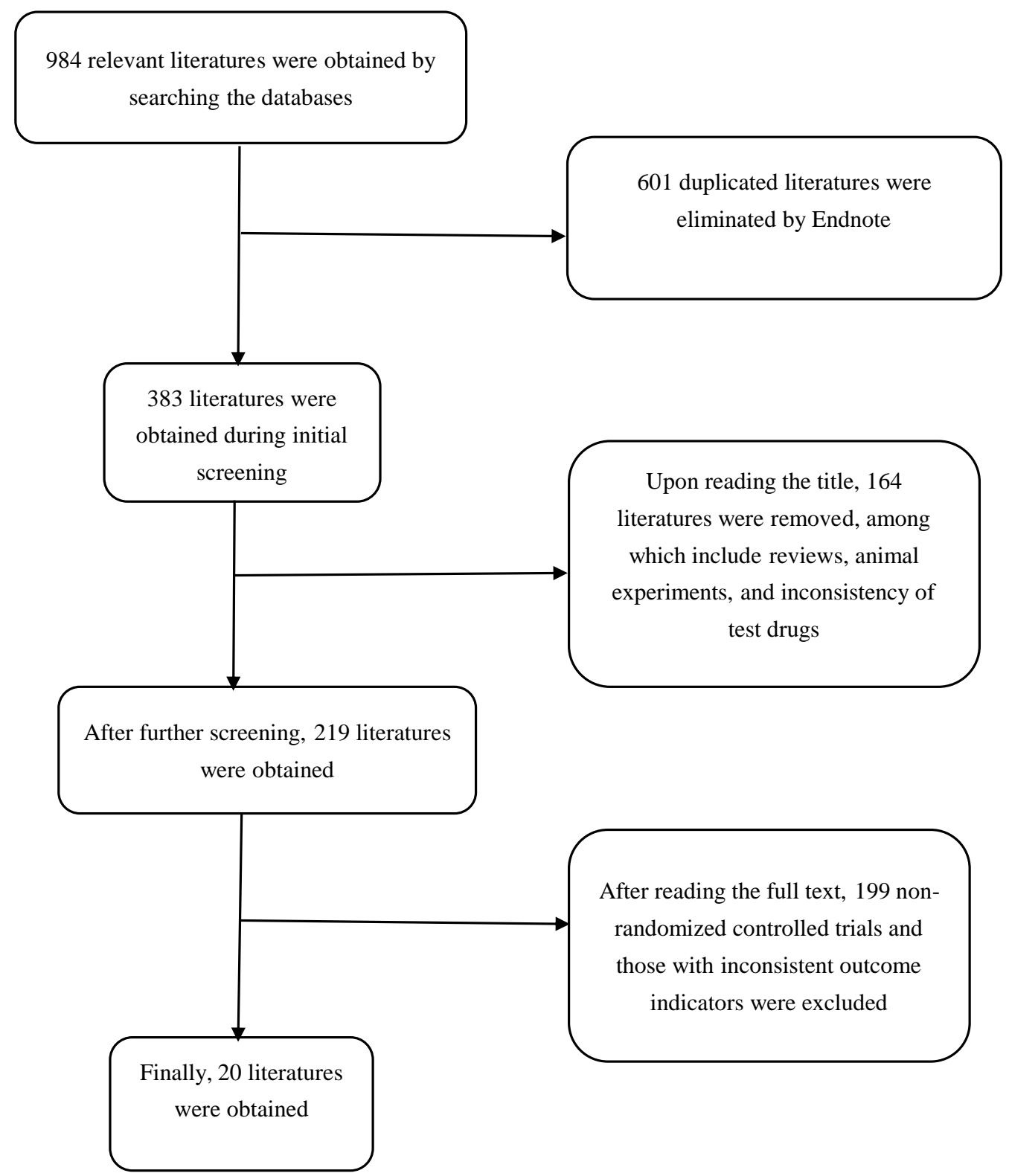

Figure 1. Flow chart of the literature retrieval process 
Table 1. Basic characteristics of the included literatures

\begin{tabular}{|c|c|c|c|c|c|c|c|c|}
\hline \multirow{2}{*}{$\begin{array}{l}\text { Author } \\
\text { and year }\end{array}$} & \multicolumn{2}{|c|}{ Average age } & \multicolumn{2}{|c|}{ Sample size / case } & \multicolumn{2}{|c|}{ Interventions } & \multirow{2}{*}{$\begin{array}{l}\text { Treatment } \\
\text { time / day }\end{array}$} & \multirow{2}{*}{$\begin{array}{l}\text { Outcome } \\
\text { indicators }\end{array}$} \\
\hline & $\begin{array}{c}\text { Experimental } \\
\text { group }\end{array}$ & $\begin{array}{l}\text { Control } \\
\text { group }\end{array}$ & $\begin{array}{c}\text { Experimental } \\
\text { group }\end{array}$ & $\begin{array}{l}\text { Control } \\
\text { group }\end{array}$ & $\begin{array}{c}\text { Experimental } \\
\text { group }\end{array}$ & Control group & & \\
\hline $\begin{array}{l}\text { Huiyuan } \\
\text { Feng } 2014\end{array}$ & $48 \pm 12$ & $49 \pm 12$ & 30 & 30 & $\begin{array}{c}\text { Shenfu }+ \\
\text { conventional } \\
\text { therapy }\end{array}$ & $\begin{array}{c}\text { Conventional } \\
\text { therapy }\end{array}$ & 72 hours & (3) (4) \\
\hline $\begin{array}{l}\text { Handong } \\
\text { Zou } 2012\end{array}$ & $42.6 \pm 16.8$ & $42.6 \pm 16.8$ & 30 & 18 & $\begin{array}{c}\text { Shenfu }+ \\
\text { conventional } \\
\text { therapy }\end{array}$ & $\begin{array}{c}\text { Conventional } \\
\text { therapy }\end{array}$ & 72 hours & $\begin{array}{c}\text { (1) } 23 \\
\text { (4) }\end{array}$ \\
\hline $\begin{array}{l}\text { Yuanyuan } \\
\text { Luo } 2018\end{array}$ & $43.35 \pm 4.31$ & $41.20 \pm 4.34$ & 30 & 30 & $\begin{array}{c}\text { Shenfu }+ \\
\text { conventional } \\
\text { therapy }\end{array}$ & $\begin{array}{c}\text { Conventional } \\
\text { therapy }\end{array}$ & 7 days & (3) 5 \\
\hline $\begin{array}{c}\text { Xi Song } \\
2015\end{array}$ & $48 \pm 12$ & $49 \pm 11$ & 30 & 30 & $\begin{array}{c}\text { Shenfu }+ \\
\text { conventional } \\
\text { therapy }\end{array}$ & $\begin{array}{c}\text { Conventional } \\
\text { therapy }\end{array}$ & 3 days & (3) (4) \\
\hline $\begin{array}{c}\text { Xiping } \\
\text { Wu } 2012\end{array}$ & $59.64 \pm 11.85$ & $\begin{array}{c}59.64 \pm \\
11.85\end{array}$ & 25 & 25 & $\begin{array}{c}\text { Shenfu }+ \\
\text { conventional } \\
\text { therapy }\end{array}$ & $\begin{array}{c}\text { Conventional } \\
\text { therapy }\end{array}$ & 7 days & (1) (4) \\
\hline $\begin{array}{c}\text { Min Liu } \\
2015\end{array}$ & $53.7 \pm 7.62$ & $52.9 \pm 8.95$ & 25 & 20 & $\begin{array}{c}\text { Shenfu }+ \\
\text { conventional } \\
\text { therapy }\end{array}$ & $\begin{array}{c}\text { Conventional } \\
\text { therapy }\end{array}$ & 7 days & (3) 5 \\
\hline $\begin{array}{c}\text { Maoen } \\
\text { Lin } 2014\end{array}$ & $58.4 \pm 12.8$ & $56.8 \pm 11.7$ & 30 & 30 & $\begin{array}{c}\text { Shenfu }+ \\
\text { conventional } \\
\text { therapy }\end{array}$ & $\begin{array}{c}\text { Conventional } \\
\text { therapy }\end{array}$ & 14 days & (4) 5 \\
\hline $\begin{array}{c}\text { Tao Liu } \\
2014\end{array}$ & $58.3 \pm 15.9$ & $58.3 \pm 15.9$ & 45 & 27 & $\begin{array}{c}\text { Shenfu }+ \\
\text { conventional } \\
\text { therapy }\end{array}$ & $\begin{array}{c}\text { Conventional } \\
\text { therapy }\end{array}$ & 7 days & (4) 5 \\
\hline $\begin{array}{c}\text { Qiqi She } \\
2017\end{array}$ & 51.5 & 54.5 & 30 & 30 & $\begin{array}{c}\text { Shenfu }+ \\
\text { conventional } \\
\text { therapy }\end{array}$ & $\begin{array}{c}\text { Conventional } \\
\text { therapy }\end{array}$ & 14 days & (1) \\
\hline $\begin{array}{l}\text { Feng } \\
\text { Geng } \\
2019\end{array}$ & $48.2 \pm 7.5$ & $44.8 \pm 8.7$ & 34 & 34 & $\begin{array}{c}\text { Shenfu }+ \\
\text { conventional } \\
\text { therapy }\end{array}$ & $\begin{array}{c}\text { Conventional } \\
\text { therapy }\end{array}$ & 7 days & (2) \\
\hline $\begin{array}{l}\text { Yangchun } \\
\text { Xiao } 2017\end{array}$ & $65.72 \pm 12.24$ & $\begin{array}{c}66.42 \pm \\
13.75\end{array}$ & 36 & 35 & $\begin{array}{c}\text { Shenfu }+ \\
\text { conventional } \\
\text { therapy }\end{array}$ & $\begin{array}{c}\text { Conventional } \\
\text { therapy }\end{array}$ & 5 days & (1) (2) \\
\hline $\begin{array}{c}\text { Xiaoxun } \\
\text { Huang } \\
2016\end{array}$ & $55 \pm 6$ & $57 \pm 8$ & 20 & 20 & $\begin{array}{c}\text { Shenfu }+ \\
\text { conventional } \\
\text { therapy }\end{array}$ & $\begin{array}{c}\text { Conventional } \\
\text { therapy }\end{array}$ & 7 days & (1) (2) \\
\hline $\begin{array}{c}\text { Jiayin Li } \\
2012\end{array}$ & $64.38 \pm 6.05$ & $70.25 \pm 4.27$ & 8 & 8 & $\begin{array}{c}\text { Shenfu }+ \\
\text { conventional } \\
\text { therapy }\end{array}$ & $\begin{array}{c}\text { Conventional } \\
\text { therapy }\end{array}$ & 6 days & (1) (2) \\
\hline $\begin{array}{c}\text { Lanting } \\
\text { Tao } 2019\end{array}$ & $68 \pm 20.3$ & $65 \pm 18.4$ & 24 & 25 & $\begin{array}{c}\text { Shenfu }+ \\
\text { conventional } \\
\text { therapy }\end{array}$ & $\begin{array}{c}\text { Conventional } \\
\text { therapy }\end{array}$ & 7 days & (1) \\
\hline $\begin{array}{c}\text { Sheng } \\
\text { Yao } 2015\end{array}$ & $63.3 \pm 11.4$ & $63.2 \pm 6.6$ & 20 & 20 & $\begin{array}{c}\text { Shenfu }+ \\
\text { conventional } \\
\text { therapy }\end{array}$ & $\begin{array}{c}\text { Conventional } \\
\text { therapy }\end{array}$ & 15 days & (1) \\
\hline
\end{tabular}




\begin{tabular}{|c|c|c|c|c|c|c|c|c|}
\hline \multirow{2}{*}{$\begin{array}{l}\text { Author } \\
\text { and year }\end{array}$} & \multicolumn{2}{|c|}{ Average age } & \multicolumn{2}{|c|}{ Sample size / case } & \multicolumn{2}{|c|}{ Interventions } & \multirow{2}{*}{$\begin{array}{l}\text { Treatment } \\
\text { time / day }\end{array}$} & \multirow{2}{*}{$\begin{array}{l}\text { Outcome } \\
\text { indicators }\end{array}$} \\
\hline & $\begin{array}{c}\text { Experimental } \\
\text { group }\end{array}$ & $\begin{array}{l}\text { Control } \\
\text { group }\end{array}$ & $\begin{array}{c}\text { Experimental } \\
\text { group }\end{array}$ & $\begin{array}{l}\text { Control } \\
\text { group }\end{array}$ & $\begin{array}{c}\text { Experimental } \\
\text { group }\end{array}$ & Control group & & \\
\hline $\begin{array}{l}\text { Manli Liu } \\
2017\end{array}$ & $60.47 \pm 12.78$ & $\begin{array}{c}62.56 \pm \\
10.79\end{array}$ & 42 & 40 & $\begin{array}{c}\text { Shenfu }+ \\
\text { conventional } \\
\text { therapy }\end{array}$ & $\begin{array}{c}\text { Conventional } \\
\text { therapy }\end{array}$ & 7 days & (1) (2) \\
\hline $\begin{array}{l}\text { Ying Cui } \\
2018\end{array}$ & $58.2 \pm 12.0$ & $59.1 \pm 10.4$ & 40 & 40 & $\begin{array}{c}\text { Shenfu }+ \\
\text { conventional } \\
\text { therapy }\end{array}$ & $\begin{array}{c}\text { Conventional } \\
\text { therapy }\end{array}$ & 7 days & (1) 2 \\
\hline $\begin{array}{l}\text { Lei Wang } \\
2018\end{array}$ & $53.16 \pm 12.08$ & $\begin{array}{c}52.63 \pm \\
12.75\end{array}$ & 51 & 51 & $\begin{array}{c}\text { Shenfu }+ \\
\text { conventional } \\
\text { therapy }\end{array}$ & $\begin{array}{c}\text { Conventional } \\
\text { therapy }\end{array}$ & 14 days & (1) (2) \\
\hline $\begin{array}{c}\text { Ronglin } \\
\text { Jiang } 2009\end{array}$ & $65.4 \pm 12.1$ & $68.8 \pm 12.9$ & 27 & 25 & $\begin{array}{c}\text { Shenfu }+ \\
\text { conventional } \\
\text { therapy }\end{array}$ & $\begin{array}{c}\text { Conventional } \\
\text { therapy }\end{array}$ & 5 days & (1) \\
\hline $\begin{array}{l}\text { Xianglian } \\
\text { Zou } 2015\end{array}$ & $53.96 \pm 10.55$ & $\begin{array}{c}50.32 \pm \\
13.74\end{array}$ & 32 & 32 & $\begin{array}{c}\text { Shenfu }+ \\
\text { conventional } \\
\text { therapy }\end{array}$ & $\begin{array}{c}\text { Conventional } \\
\text { therapy }\end{array}$ & 7 days & (1) \\
\hline
\end{tabular}

Note: (1) 28-day mortality rate; (2) length of stay in ICU; (3) cTnI; (4) NT-ProBNP; (5) LVEF

\subsection{Quality evaluation}

Among the 20 literatures, 8 adopted the random number table method ${ }^{[6,9,14,16-18,20,23]}$, while only 1 adopted the envelope lottery method ${ }^{[10]}$. All 20 literatures did not adopt the blind method, but since the outcome indicators are laboratory examination results and objective indicators, which do not affect the judgment of the results, it can be considered that the blind method adopted by the analyst is of low risk, it is impossible to report the results selectively with 20 articles, and there is no bias from other sources in the literatures. Only two literatures reported adverse reactions ${ }^{[16,19]}$; there were uncertainties in other studies. Only ten literatures mentioned about signing an informed consent or obtaining the consent of patients or family members ${ }^{[6,8,10,12-14,20,22-24]}$. The risk of bias of each study is shown in Figure 2.

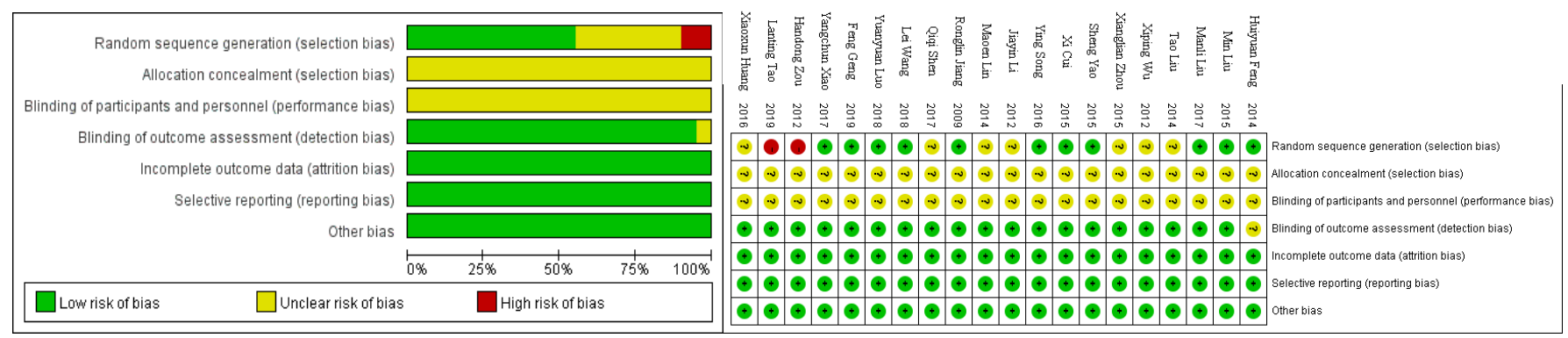

Figure 2. Risk-of-bias

\subsection{8-day mortality rate}

There were 13 literatures with the outcome of 28-day mortality rate. The results showed that there was no heterogeneity among the studies $\left(\mathrm{P}=0.37, \mathrm{I}^{2}=7 \%\right)$; thus, the fixed effect model was used. The results showed that Shenfu injection can reduce the 28-day mortality rate of patients with sepsis $(\mathrm{RR}=0.65,95 \%$ CI [0.53,0.80], P $<0.0001]$, as shown in Figure 3. 


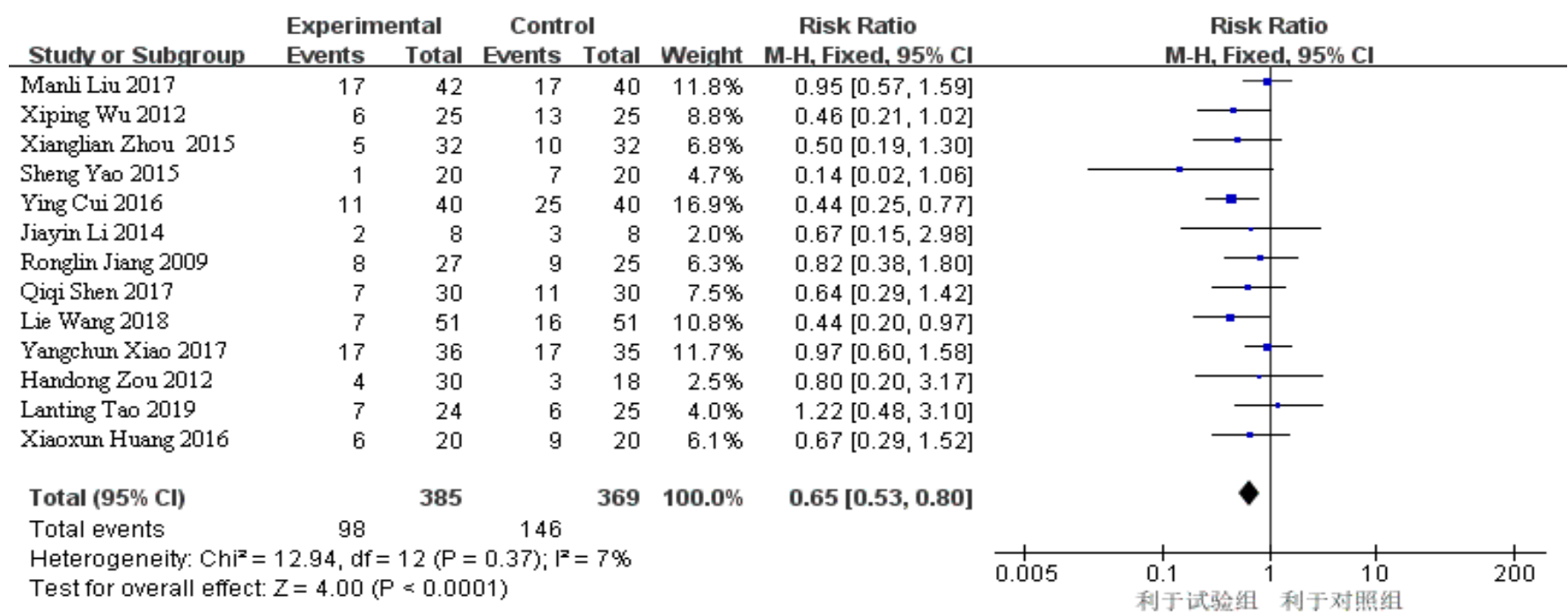

Figure 3. Forest plot of 28-day mortality rate

\subsection{Length of stay in ICU}

There were 8 literatures with the outcome of the length of stay in ICU. The results showed no significant heterogeneity $\left(\mathrm{P}=0.11, \mathrm{I}^{2}=40 \%\right)$; thus, the fixed effect model was used. The results showed that Shenfu injection can shorten the length of stay in ICU for patients with sepsis (MD $=-2.04,95 \%$ CI [- 2.91, - 1.17], $\mathrm{P}<0.00001$ ), as shown in Figure 4.

\begin{tabular}{|c|c|c|c|c|c|c|c|c|c|c|c|c|}
\hline Studv or Subgroup & \multicolumn{3}{|c|}{ Experimental } & \multicolumn{2}{|c|}{ Control } & Total & Weight & \multicolumn{2}{|l|}{ Mean Difference } & \multicolumn{2}{|c|}{$\begin{array}{l}\text { Mean Difference } \\
\text { IV, Fixed, } 95 \% \mathrm{Cl}\end{array}$} & \\
\hline Marli Liu 2017 & 9.45 & 4.32 & 42 & 9.79 & 5.02 & 40 & $18.5 \%$ & $-0.34[-2.37,1.69]$ & & & & \\
\hline Ying Cui 2016 & 14.3 & 6.7 & 40 & 17.7 & 7.9 & 40 & $7.4 \%$ & $-3.40[-6.61,-0.19]$ & & & & \\
\hline Jiayin Li 2012 & 27 & 14.2 & 8 & 29 & 13.5 & 8 & $0.4 \%$ & $-2.00[-15.58,11.58]$ & & & & \\
\hline Lei Wang 2018 & 6.03 & 3.28 & 51 & 9.15 & 4.89 & 51 & $29.2 \%$ & $-3.12[-4.74,-1.50]$ & & - & & \\
\hline Feng Geng 2019 & 10.6 & 5.2 & 34 & 14.6 & 4.13 & 34 & $15.3 \%$ & $-4.00[-6.23,-1.77]$ & & & & \\
\hline Yangchun Xiao 2017 & 9.35 & 5.23 & 36 & 9.56 & 5.35 & 35 & $12.6 \%$ & $-0.21[-2.67,2.25]$ & & & & \\
\hline Handong Zou 2012 & 9.35 & 3.2 & 30 & 10.12 & 4.13 & 18 & $15.4 \%$ & $-0.77[-3.00,1.46]$ & & & & \\
\hline Xiaoxun Huang 2016 & 15 & 11 & 20 & 19 & 14 & 20 & $1.3 \%$ & $-4.00[-11.80,3.80]$ & & & & \\
\hline Total $(95 \% \mathrm{Cl})$ & & & 261 & & & 246 & $100.0 \%$ & $-2.04[-2.91,-1.17]$ & & & & \\
\hline $\begin{array}{l}\text { Heterogeneity: } \mathrm{Chi}^{2} \\
\text { Test for overall effect }\end{array}$ & $\begin{array}{l}11.67, d \\
Z=4.58\end{array}$ & $\begin{array}{l}f=7(\mathrm{P} \\
(\mathrm{P}<0\end{array}$ & $\begin{array}{l}=0.11 \\
.00001\end{array}$ & $\left.i_{1}\right|^{2}=$ & & & & & -20 & $\begin{array}{l}-10 \\
\text { 利于试验组 }\end{array}$ & 利于对照组 & 20 \\
\hline
\end{tabular}

Figure 4. Forest plot of the length of stay in ICU

\section{5. cTnI}

In total, there were 5 literatures with the outcome of cTnI levels. Due to high heterogeneity, only systematic evaluation was carried out. The results showed that Shenfu injection can reduce the cTnI levels in patients with sepsis, and the difference was statistically significant.

\subsection{NT-proBNP}

There were 6 literatures with the outcome of NT-proBNP. Due to high heterogeneity, only systematic evaluation was carried out. The results showed that Shenfu injection can reduce the NT-proBNP levels in patients with sepsis, and the difference was statistically significant. 


\subsection{LVEF}

There were 4 articles with the outcome of LVEF. The results showed that the heterogeneity was slightly higher $\left(\mathrm{P}=0.06, \mathrm{I}^{2}=59 \%\right)$; thus, the random effect model was used. The results showed that Shenfu injection can reduce $\mathrm{LVEF}$ in patients with sepsis $(\mathrm{MD}=6.03,95 \% \mathrm{CI}[2.40,9.66], \mathrm{P}=0.001)$, as shown in Figure 5.

\begin{tabular}{|c|c|c|c|c|c|c|c|c|c|c|c|c|}
\hline \multirow[b]{2}{*}{ Studv or Subgroup } & \multicolumn{3}{|c|}{ Experimental } & \multicolumn{2}{|c|}{ Control } & \multirow[b]{2}{*}{ Total } & \multirow[b]{2}{*}{ Weight } & \multirow{2}{*}{$\begin{array}{l}\text { Mean Difference } \\
\text { IV, Random, 95\% Cl }\end{array}$} & \multirow{2}{*}{\multicolumn{3}{|c|}{$\begin{array}{c}\text { Mean Difference } \\
\text { IV, Random, 95\% Cl }\end{array}$}} & \\
\hline & Mean & SD & Total & Mean & SD & & & & & & & \\
\hline Min Liu 2015 & 51.12 & 9.88 & 25 & 49.4 & 10.28 & 20 & $20.1 \%$ & $1.72[-4.22,7.66]$ & & & & \\
\hline Tao Liu 2014 & 62.97 & 13.02 & 45 & 56.16 & 11.31 & 27 & $20.9 \%$ & $6.81[1.09,12.53]$ & & & & \\
\hline Maoen Liu 2014 & 56.35 & 7.68 & 30 & 52.05 & 7.95 & 30 & $28.7 \%$ & $4.30[0.34,8.26]$ & & & & \\
\hline Yuanyuan Lou 2018 & 65 & 7.56 & 30 & 55 & 6.78 & 30 & $30.3 \%$ & $10.00[6.37,13.63]$ & & & - & \\
\hline Total $(95 \% \mathrm{Cl})$ & & & 130 & & & 107 & $100.0 \%$ & $6.03[2.40,9.66]$ & & & & \\
\hline $\begin{array}{l}\text { Heterogeneity: Tau } \\
\text { Test for overall effec }\end{array}$ & $\begin{array}{l}7.88 ; C \\
Z=3.26\end{array}$ & $\begin{array}{l}h i^{2}=7.2 \\
(P=0 .\end{array}$ & $\begin{array}{l}5, d f= \\
001)\end{array}$ & $3(P=$ & $.06) ;\left.\right|^{2}=$ & $59 \%$ & & & -50 & $\begin{array}{l}-25 \\
\text { 利于对典组 }\end{array}$ & 利于试验组 & ${ }_{50}^{7}$ \\
\hline
\end{tabular}

Figure 5. Forest plot of LVEF

\subsection{Adverse reactions}

There were 2 literatures that reported on the adverse reactions of Shenfu injection, both of which indicated no adverse reactions. Other literatures had no information regarding this matter. Therefore, it can be inferred that the incidence of adverse reactions from Shenfu injection may be low. Researchers should pay more attention to the adverse reactions of this drug in the future.

\subsection{Sensitivity analysis}

By eliminating the literatures one by one, the observation was on whether the outcome indexes had changed significantly. The combined results did not change significantly, indicating that the results are robust and reliable.

\subsection{Publication bias}

The publication bias of the 28 -day mortality rate was evaluated with $\geq 10$ references included. It can be seen from Figure 6 that the studies on both the left- and right-hand side of the funnel plot are evenly distributed, indicating that there is no publication bias.

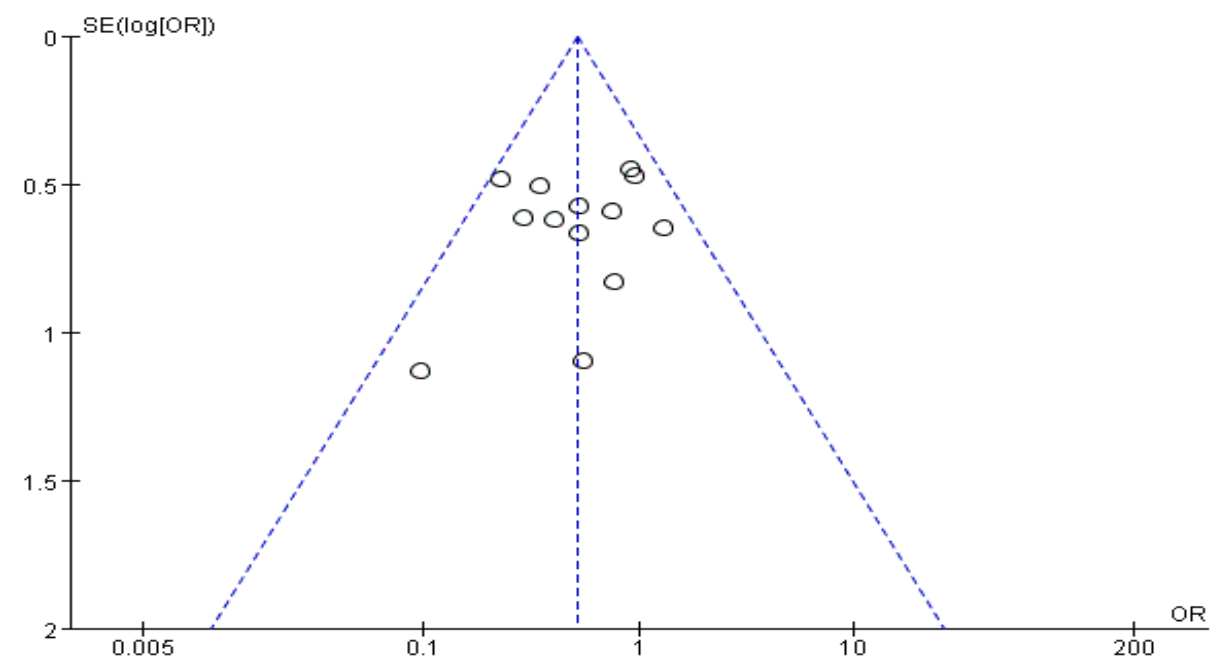

Figure 6. Funnel plot of 28-day mortality rate 


\section{Discussion}

Septic cardiomyopathy has always been the focus of scholars, but there is no consensus on its diagnosis or treatment. Currently, it is generally believed that the downregulation of myocardial inhibitory factors and $\beta$ adrenergic receptors, abnormal calcium ion transport in cardiomyocytes, and mitochondrial dysfunction may be related to the pathogenesis of septic cardiomyopathy. Cardiomyocyte injury, decreased cardiac output, and ventricular dilation are the main clinical manifestations of septic cardiomyopathy ${ }^{[26,27]}$. CTnI, NT-ProBNP, and LVEF are common clinical indicators for the evaluation of septic cardiomyopathy ${ }^{[28]}$. The rapid increase of cTnI levels in the initial stage of septic cardiomyopathy is a highly sensitive and specific clinical index for the diagnosis of myocardial injury. When there is damage to cardiomyocytes, myocardial contractility weakens, stroke output decreases, and the synthesis of pro-BNP increases. Enzyme-cleaved NT-proBNP reflects the state of cardiac function more accurately. The increase of NTproBNP is positively correlated with the severity of cardiac dysfunction; LVEF is used as the evaluation index of systolic heart failure ${ }^{[29,30]}$. Generally, LVEF in patients with cardiac insufficiency is less than $50 \%$. At present, the treatment of septic cardiomyopathy still focuses on symptomatic support, such as rehydration, cardiac strengthening, and blood pressure stabilization ${ }^{[26]}$, without any specific treatment.

The basic pathogenesis of sepsis is based on deficiency, marked by excess, and mixed with deficiency and excess. Positive deficiency is not only the basis of onset but also a prominent manifestation after the progress of the disease. Septic cardiomyopathy mostly occurs in the mid and late stages of sepsis. It is closely related to the lack of healthy Qi in the body. Shenfu injection is made from a classic prescription of "warming Yang and supplementing Qi." In the prescription, Radix Aconiti Lateralis Preparata is hot and goes through various meridians to recover the scattered Yin-Yang; Radix Ginseng Rubra helps to regulate various deficiencies. The two drugs are compatible in restoring healthy Qi to the body. Modern research of traditional Chinese medicine reports that aconitine contained in Shenfu injection has positive inotropic effect on the heart, while ginsenoside has obvious effects in scavenging free radicals, strengthening the heart, and stabilizing blood pressure ${ }^{[31,32]}$. Animal experiments have shown that the Chinese patent medicine can reduce myocardial inhibitory factors, improve $\mathrm{Na}^{+} / \mathrm{K}^{+}$-ATPase activity in cardiomyocytes, and improve mitochondrial function ${ }^{[33-36]}$. This meta-analysis also shows that the use of Shenfu injection with conventional treatment can further reduce cTnI and NT-proBNP levels, increase LVEF, and improve the prognosis of patients with septic cardiomyopathy.

The limitations in this meta-analysis are as follows: the included literatures are of low quality, the diagnostic criteria are inconsistent among different studies due to time differences; there are differences in the usage, dosage, and treatment time of Shenfu injection; there are also differences in the methods and the course of conventional western treatment, which may be the source of heterogeneity in the results of this meta-analysis. It is hoped that the future clinical trial design would be more standardized.

\section{Disclosure statement}

The authors declare that there is no conflict of interest.

\section{References}

[1] Frencken JF, Donker DW, Spitoni C, et al., 2018, Myocardial Injury in Patients With Sepsis and Its Association with Long-Term Outcome. Circ Cardiovasc Qual Outcomes, 11(2): e004040.

[2] Zheng Z, Ma H, Zhang X, et al., 2017, Enhanced Glycolytic Metabolism Contributes to Cardiac Dysfunction in Polymicrobial Sepsis. J Infect Dis, 215(9): 1396-1406. 
[3] Rumery K, Yunus F, Frishman WH, 2020, Myocardial Depression in Sepsis: Beneficial Adaptation or Sequelae that Requires Treatment?. Cardiol Rev, 28(5): 256-261.

[4] Yang L, Yue J, Luo Y, et al., 2018, Research Progress of Shenfu Injection in the Treatment of Myocardial inhibition in Sepsis. Chinese Medicine Modern Distance Education of China, 16(5): 149151.

[5] Zou H, Zhou Qi, Zhou C, et al., 2012, Protective Effect of Shenfu Injection on Myocardial Injury in Patients with Sepsis. China Medical Herald, 9(13): 77-78, 87.

[6] Luo Y, Zhao F, Chen W, et al., 2018, Clinical Study of Shenfu Injection on Myocardial Injury in Patients with Sepsis. Journal of Emergency in Traditional Chinese Medicine, 27(11): 1930-1932.

[7] Higgins JPT, Thomas J, Chandler J, et al., (eds) 2021, Cochrane Handbook for Systematic Reviews of Interventions Version 6.2. Cochrane. www.training.cochrane.org/handbook (updated on February 2021).

[8] Zhou X, Lin M, Yu Y, 2015, Influence of Shenfu Injection on Hemorheology and Prognosis of Patients with Severe Sepsis. Chongqing Medicine, 44(36): 5157-5159.

[9] Yao S, 2015, Effects of Shenfu Injection on Systemic Circulation, Oxygen Metabolism and Prognosis in Patients with Septic Shock. Shenzhen Journal of Integrated Traditional Chinese and Western Medicine, 25(24): 23-25.

[10] Xiao Y, Li Y, Wang G, et al., 2017, Clinical Observation of Shenfu Injection in Treatment of Septic Shock Patients. Journal of Emergency in Traditional Chinese Medicine, 26(9): 1665-1667.

[11] Wu X, Wu H, Guan Y, et al., 2012, Effect of Shenfu Injection on Early Plasma NT-proBNP in Patients with Sepsis. Journal of Emergency in Traditional Chinese Medicine, 21(12): 2035-2036.

[12] Wang L, Qi H, Zhang W, et al., 2018, Effects of Shenfu Injection on D-Lactic Acid and Inflammatory Factors in Patients with Severe Sepsis. Journal of Clinical Emergency, 19(1): 17-20.

[13] Tao L, 2019, Clinical Observation of Fuzheng Guben Method in the Treatment of Sepsis. Journal of Guangzhou University of Traditional Chinese Medicine, 36(10): 1535-1539.

[14] Song X, Shen Y, Yuan Z, 2015, Effects of Shenfu Injection on Serum Troponin I, N-Terminal Pro-brain Natriuretic Peptide Levels and Cardiac Index in Patients with Sepsis. Practical Journal of Cardiac Cerebral Pneumal and Vascular Disease, 44: 151-152.

[15] Liu T, Lv B, Huang R, et al., 2014, Effect of Shenfu Injection on Cardiac Function inPatients with Septic Myocardial Injury. Shandong Medical Journal, 000(026): 69-71.

[16] Liu M, 2015, Clinical Observation of Shenfu Injection on Myocardial Injury in Sepsis. Guangzhou University of Chinese Medicine.

[17] Liu M, Ye B, Shi X, 2017, Efficacy Analysis of Shenfu Injection in Patients with Aeptic Shock. Journal of Imaging Research and Medical Applications, 1: 171-173.

[18] Lin M, Pan S, Zeng W, et al., 2014, Effects of Shenfu Injection on Cardiac Function and Plasma NTproBNP in Patients with Sepsis Myocardial Injury. Modern Practical Medicine, 26(10): 1265-1266.

[19] Li J, 2012, Clinical Study of Shenfu Injection in the Treatment of Septic Shock. Zhejiang University.

[20] Jiang R, Lei S, Wang L, et al., 2009, Effect of Shenfu Injection on Tissue Oxygen Metabolism in Patients with Severe Sepsis. China Journal of Traditional Chinese Medicine and Pharmacy, 24(7): 965967.

[21] Huang X, 2016, Evaluation of Hemodynamic Effect and Prognosis of Shenfu Injection in Patients with Septic Shock by PiCCO. Guangzhou University of Chinese Medicine. 
[22] Geng F, Yu L, Zhang Y, 2019, Influence of Shenfu Injection on Inflammatory Factors and Clinical Prognosis of Patients with Sepsis. Chinese Traditional Patent Medicine, 41(1): 228-230.

[23] Feng H, Li W, 2014, Protective Effect of Shenfu Injection on Myocardial Injury in Patients with Sepsis. Hebei Medical Journal, 2014(18): 2764-2765.

[24] Cui Y, Dai L, 2016, Effect of Shenfu Injection on Septic Shock and Hemodynamics. Modern Journal of Integrated Traditional Chinese and Western Medicine, 25(19): 2120-2122.

[25] Shen Q, Zhang Z, 2017, Effects of Shenfu Injection on Plasma BNP and Inflammatory Factors in Patients with Sepsis Myocardial Injury. Journal of Emergency in Traditional Chinese Medicine, 26(1): 184-185, 188.

[26] Poveda-Jaramillo R, 2021, Heart Dysfunction in Sepsis. J Cardiothorac Vasc Anesth, 35(1): 298-309.

[27] Habimana R, Choi I, Cho HJ, et al., 2020, Sepsis-Induced Cardiac Dysfunction: A Review of Pathophysiology. Acute Crit Care, 35(2): 57-66.

[28] Zeng L, Zhao Y, Jiang C, et al., 2017, Analysis of Clinical Diagnostic Bounds of Myocardial Injury Markers in the Diagnosis of Acute Myocardial Infarction. International Journal of Laboratory Medicine, 38(6): 826-828.

[29] Maisel AS, Krishnaswamy P, Nowak RM, et al., 2022, Rapid Measurement of B-Type Natriuretic Peptide in the Emergency Diagnosis of Heart Failure. N Engl J Med, 347(3): 161-167.

[30] Gong H, Luo X, 2010, Application Progress of BNP and NT-proBNP in Heart Failure. Journal of Military Surgeonin in Southwest China, 12(1): 99-101.

[31] Zhang S, Wu B, 2001, Study on Positive Inotropic Effect of Aconitine Combined with Potassium Channel Agonist on Isolated Rat Heart. Chinese Pharmacological Bulletin, 17(5): 570-572.

[32] Jiang J, Zhang S, Ji D, 2012, Handbook of Common New Drugs, Shanxi Science and Technology Press Co., Ltd., Jinan, 2000-2009.

[33] Yang W, Li P, Mi H, et al., 2018, Protective Effects of Shenfu Injection on Acute Pancreatitis in Rats. Chinese Journal of Experimental Traditional Chinese Medicine, 24(7): 159-164.

[34] Duncan DJ, Hopkins PM, Harrison SM, 2007, Negative Inotropic Effects of Tumour Necrosis FactorAlpha and Interleukin-1 $\beta$ are Ameliorated by Alfentanil in Rat Ventricular Myocytes. Br J Pharmacol, 150(6): 720-726.

[35] Yu Y, Wang S, 2013, Effect of Shenfu Injection on Mitochondrial and Inner Membrane Injury of Hypertrophic Cardiomyocytes. Chinese Materia Medica Pharmacology and Clinical, 29(4): 19-21.

[36] Xin Y, Wu Y, Gu Y, et al., 2010, Experimental Study of Shenfu Injection on Myocardial Apoptosis Induced by Ischemia/Reperfusion Injury in Rats. Journal of Cardiopulmonary and Vascular Diseases, 29(3): 229-232. 